\title{
New locality record and additional information on the habitat of Cyclestheria hislopi (Baird, 1859) (Crustacea: Branchiopoda: Cyclestherida) in India
}

\author{
Sameer M. Padhye ${ }^{1}$, Hemant V. Ghate ${ }^{2}$ \& Kalpana Pai ${ }^{3}$ \\ ${ }^{1}$ Research Fellow, ${ }^{2}$ Associate Professor, Department of Zoology, Pune University, Pune, Maharashtra 411007, India \\ ${ }^{3}$ Head, Department of Zoology, Modern College, Shivajinagar, Pune, Maharashtra 411005, India \\ Email: ${ }^{1}$ sameer.m.padhye@gmail.com, ${ }^{2}$ hemantghate@gmail.com, ${ }^{3}$ kalpanapai@unipune.ernet.in
}

\begin{abstract}
The paper reports the presence of the branchiopod Cyclestheria hislopi (Baird) in one permanent and one temporary fresh water pond near Pune City, Maharashtra.
\end{abstract}

Keywords: Branchiopoda, Cyclestheria hislopi, Maharashtra, permanent fresh water pond, Pune.

Cyclestheria hislopi is a clam shrimp in the order, Cyclestherida of the class Branchiopoda (Martin et al. 2003; Olesen 2009). This parthenogenetically breeding species consists mostly of females with rare occurrence of males in some populations. While morphological and phylogenetic aspects of Cyclestheria hislopi are well known, its ecological preferences are yet to receive attention.

Cyclestheria hislopi described from Nagpur, India, by Baird (1859) as Estheria hislopi was transferred

Date of publication (online): 26 January 2011

Date of publication (print): 26 January 2011

ISSN $0974-7907$ (online) | 0974-7893 (print)

Editor: Stephen C. Weeks

Manuscript details:

Ms \# 02335

Received 20 October 2009

Final received 15 December 2010

Finally accepted 21 December 2010

Citation: Padhye, S.M., H.V. Ghate \& K. Pai (2011). New locality record and additional information on the habitat of Cyclestheria hislopi (Baird, 1859) (Crustacea: Branchiopoda: Cyclestherida) in India. Journal of Threatened Taxa 3(1): 1445-1448.

Copyright: (C) Sameer M. Padhye, Hemant V. Ghate \& Kalpana Pa 2011. Creative Commons Attribution 3.0 Unported License. JoTT allows unrestricted use of this article in any medium for non-profit purposes, reproduction and distribution by providing adequate credit to the authors and the source of publication.

Acknowlegements: We thank Dr. Jørgen Olesen (Denmark) for help and critical review; Dr. Michael Korn (Germany) for help in identification and literature; Dr. Gunale of the Botany Department, University of Pune for help in identification of phytoplankton; authorities of Modern College, and Zoology Department of Pune University for facilities and CSIR for financial support.

\section{OPEN ACCESS | FREE DOWNLOAD (C) (i) (4)}

to a new family, Cyclestheriidae, by Sars, in 1889 (Olesen et al. 1996). Later Nayar \& Nair (1967) and Nair (1968) reported it from Kerala, and Battish (1981) from Punjab, India. Paul \& Nayar (1977) studied populations of Cyclestheria in Kerala and reported that they were found in shallow, temporary ponds with plenty of rooted vegetation and were predominantly associated with the weed Hydrilla verticillata. It is pan-tropical in occurrence between $30^{\circ} \mathrm{N} \& 35^{\circ} \mathrm{S}$ and has been reported from Australia, Africa, the Americas and various parts of Asia (Olesen et al. 1996); it occurs also in permanent water bodies in addition to temporary pools. Males are known from four sites only, all of which are either in the northern or southern extremes of range. In this note we report a new locality of occurrence of Cyclestheria hislopi, with additional observations on the physico-chemical parameters.

\section{Methods}

Samples of Cyclestheria hislopi were collected as a part of our survey for invertebrates in various small ephemeral or permanent ponds in the Pune environs, with a net (mesh about $300 \mu \mathrm{m}$ ) swept at an approximate depth of $6 \mathrm{~cm}$ in both the localities. It was found in two man-made ponds, a permanent one, Ganesh Talav $\left(18^{0} 39^{\prime} 9.28^{\prime \prime} \mathrm{N} \& 73^{\circ} 45^{\prime} 46.75^{\prime \prime} \mathrm{E}\right)$ (Images $\left.1 \& 2\right)$ and a temporary pond near Dighi Town $\left(18^{\circ} 35^{\prime} 58.68^{\prime \prime} \mathrm{N}\right.$ \& 73052'37.14”E) (Images $3 \& 4$ ). Maximum depth of both the ponds was approximately $2 \mathrm{~m}$. Ganesh Talav is approximately $50 \mathrm{~m}$ long and $25 \mathrm{~m}$ wide and has aquatic vegetation, mainly of Hydrilla sp., while the pond near Dighi is about $25 \mathrm{~m}$ long and $15 \mathrm{~m}$ wide lacking rooted aquatic vegetation. Both the ponds are close to rivers but distinct.

Sample collection was done from October 2008 to May 2009 in Ganesh Talav, while in Dighi from 

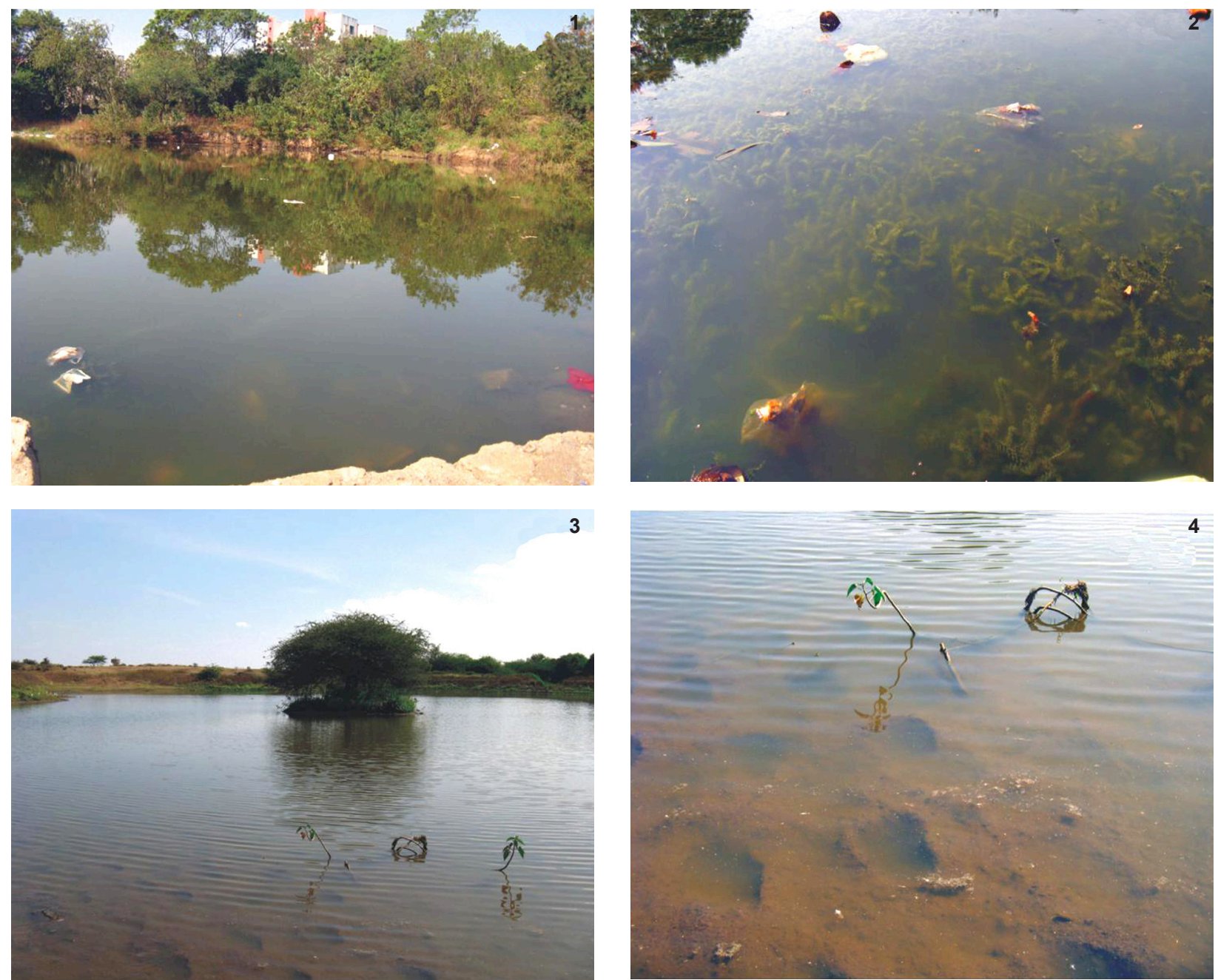

Images 1-4. Habitats studied.

1 \& 2 - The Dighi Pond; 3 \& 4 - Ganesh Talav (๔ Hemant Ghate \& Sameer Padhye)

December 2008 to March-April 2009. Sampling was done in February by filtering $5 \mathrm{~L}$ of water from approximately $0.3 \mathrm{~m}^{2}$ area in a single site for one day. Samples were preserved in $4 \%$ formalin for identification of Cyclestheria hislopi as well as the phytoplankton. Physico-chemical parameters (conductivity, salinity, and total dissolved solids) of both habitats were recorded in the field with portable EUTECH Multi-parameter PCS Tester 35. Samples were dissected and photographed under Kyowa or Leica MZ6 Stereomicroscope with attached Canon Powershot digital camera. Measurements were made using ERMA stage and ocular micrometer.

\section{Results}

The aquatic vegetation of Ganesh Talav mainly consisted of Hydrilla spread all over. The pond also had the guppy Lebistes reticulatus, insect larvae and dragonfly nymphs. Water level in the pond was more or less same during the collection period, maximum depth being 1.5-2 m. Cyclestheria hislopi was found in low densities in Ganesh Talav (Images 5 \& 6).

The pond near Dighi was ephemeral and received water from the start of monsoon (July) and it remained filled till the end of March 2009. Aquatic vegetation was absent during most of the monsoon period, but during the last 20 days of March, algal mats were observed in a few places. The maximum depth of the pond was $1 \mathrm{~m}$. Density of Cyclestheria hislopi was much higher in this pond than in Ganesh Talav and it increased as the pond started drying.

Preliminary analysis of the phytoplankton composition of the two ponds showed the presence of diatoms and, to a lesser degree, green algae. Members 

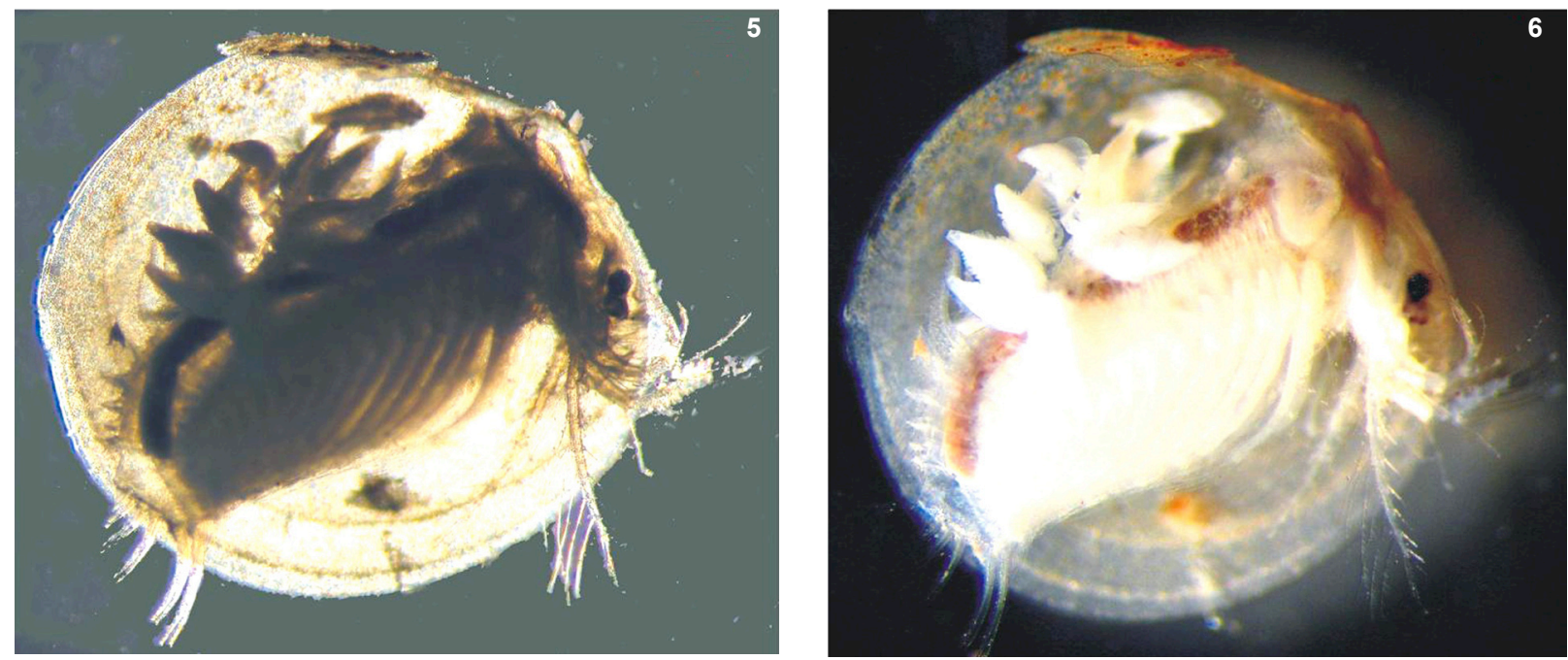

Images 5-6. Cyclestheria hislopi.

5 - Parthenogenetic female of Cyclestheria hislopi in transmitted light; 6 - Parthenogenetic females of $C$. hislopi in incident light (๑ Hemant Ghate \& Sameer Padhye)

of the diatom genera Fragillaria, Oscillatoria, Nitzschia, Navicula, and Cymbella were observed. Green algal species of Eudorina and Actinastrum and Spirogyra were seen, but the last was not very abundant. Composition of phytoplankton in both the ponds was similar.

Physico-chemical features of the two habitats were different. Salinity, conductivity and T.D.S. were five times higher in the ephemeral pond near Dighi than in the permanent pond Ganesh Talav, while $\mathrm{pH}$ was lower (Table 1). Surface temperature was the highest in the temporary pool near Dighi (maximum of $31^{\circ} \mathrm{C}$; Table 1), as it was smaller.

\section{Discussion}

Nayar \& Nair(1968), while reporting C. hislopi from India, observed that Cyclestheria was always found in association with Hydrilla. In our case, however, it was found in temporary water bodies without vegetation. Rosseler (1995) reported the presence of Cyclestheria in permanent water bodies in Colombia. This report confirms that Cyclestheria do live in permanent water bodies (in contrast to other clam shrimps) and that they do not require aquatic vegetation. It is also found that Cyclestheria tolerate the presence of Lebistes fish. Furthermore, Cyclestheria tolerate a large variation in the physico-chemical properties, e.g., a $\mathrm{pH}$ up to 9 , temperatures up to $31^{\circ} \mathrm{C}$ and fluctuations in other parameters like conductivity. Gut composition of Cyclestheria hislopi showed the presence of diatoms, as primary food. Fish normally do not co-exist with $C$. hislopi, but Ganesh Talav offers a unique opportunity to study this coexistence. Witham et al. (1998) stated that habitats of small invertebrates, such as clam shrimps, are often overlooked and therefore destroyed. Ganesh Talav, the permanent pond in this study, is under stress since lot of organic matter is repeatedly being dumped in the pond, despite steps taken to prevent. It is very unfortunate since this pond is quite a unique habitat, being the only permanent water body harbouring

Table 1. Physico chemical properties of Ganesh Talav and Dighi Pond habitats.

\begin{tabular}{|l|c|c|c|c|c|c|c|c|c|c|}
\hline Date & \multicolumn{2}{|c|}{$\mathrm{pH}$} & \multicolumn{2}{c|}{ Temperature $\left({ }^{\circ} \mathrm{C}\right)$} & \multicolumn{2}{c|}{ Conductivity $(\mu \mathrm{s} / \mathrm{cm})$} & \multicolumn{2}{c|}{ T.D.S (ppm) } & \multicolumn{2}{c|}{ Salinity (ppt) } \\
\hline & Dighi & $\begin{array}{c}\text { Ganesh } \\
\text { Talav }\end{array}$ & Dighi & $\begin{array}{c}\text { Ganesh } \\
\text { Talav }\end{array}$ & Dighi & $\begin{array}{c}\text { Ganesh } \\
\text { Talav }\end{array}$ & \multicolumn{2}{c|}{$\begin{array}{c}\text { Dighi } \\
\begin{array}{c}\text { Ganesh } \\
\text { Talav }\end{array}\end{array} \begin{array}{c}\text { Dighi } \\
\text { Ganesh } \\
\text { Talav }\end{array}$} \\
\hline 04.ii.2009 & 8.51 & 7.82 & 28.2 & 26.5 & 547 & 338 & 389 & 234 & 0.266 & 0.154 \\
\hline 11.ii.2009 & 8.39 & 8.23 & 29.2 & 27 & 656 & 352 & 465 & 253 & 0.324 & 0.173 \\
\hline 18.ii.2009 & 8.54 & 8.95 & 31 & 28.2 & 627 & 211 & 445 & 150 & 0.305 & 0.104 \\
\hline 25.ii.2009 & 8.56 & 9.07 & 30.4 & 28.7 & 650 & 208 & 461 & 147 & 0.317 & 0.101 \\
\hline
\end{tabular}


Cyclestheria found so far in India.

\section{REFERENCES}

Baird, W. (1859). Description of some new recent Entomostraca from Nagpur, collected by the Rev. S. Hislop. Proceedings of the Royal Society of London Series B-Biological Sciences 63: 231-234.

Battish, S. K. (1981). On some conchostracans from Punjab with the description of three new species and a new subspecies. Crustaceana 40: 178-196.

Martin, J.W., S.L. Boyse \& M.J. Grygier (2003). New records of Cyclestheria hislopi (Baird, 1859) (Crustacea: Branchiopoda: Diplostraca: Cyclestherida) in South East Asia. The Raffles Bulletin of Zoology 51(2): 215-218. Nayar, C.K. \& K.K.N. Nair (1968). On a collection of Conchostraca (Crustacea: Brancbiopoda) from south India, with the description of two new species. Hydrobiologia 32: 219-224.

Nayar, C.K.G. (1967). Three new species of Conchostraca from Rajasthan. Bulletin of Systematic Zoology 1(1): 1924.
Olesen, J. (2009). Phylogeny of Branchiopoda (Crustacea) character evolution and contribution of uniquely preserved fossils. Arthropods Systematics \& Phylogeny 67: 3-39.

Olesen, J., J.W. Martin \& E.W. Roesseler (1996). External morphology of the male of Cyclestheria hislopi (Baird, 1859) (Crustacea, Branchiopoda, Spinicaudata), with a comparison of male claspers among the Conchostraca and Cladocera and its bearing on phylogeny of the 'bivalved" Branchiopoda. Zoologica Scripta 25(4): 291-316.

Paul, M.A. \& C.K.G. Nayar (1977). Studies on a natural population of Cyclestheria hislopi (Baird) (Conchostraca: Crustacea). Hydrobiologia 532: 173- 179.

Roessler, E.W. (1995). Review of Colombian Conchostraca (Crustacea) - ecological aspects and life cycles - family Cyc1estheriidae. Hydrobiologia 298: 125-132.

Witham, C.W., E.T. Bauder, D. Belk, W.R. Ferren, Jr \& R. Ornduff (1998). Global status and trends in ephemeral pool invertebrate conservation: implications for californian fairy shrimp, pp. 147-150. Ecology, Conservation, and Management of Vernal Pool Ecosystems - Proceedings from a 1996 Conference. California Native Plant Society, Sacramento, CA. 1998. 